\title{
PRODUCT TRIAL PROCESSING (PTP): A MODEL APPROACH FROM THECONSUMER'S PERSPECTIVE
}

\author{
SUNDAY O. E. EWAH AND ATIM E. ESANG
}

(Received 9, September 2008; Revision Accepted 12, August 2009)

\begin{abstract}
This study is a theoretical approach to consumer's processing of product trail, and equally explored the literature of product levels, concept benefit and life cycle. Product trial is described as consumer's first usage experience with a company's brand or product that is most important in determining brand attributes and the intention to make a purchase. Among the constructs used in the model of consumer's processing of product trail includes; experiential and non- experiential attributes, perceived validity of product trial, consumer perceived expertise, perceived diagnosticity of product trail, others are emotions, evaluations of trail performance and attitude towards a brand. In conclusion it is believed that consumers processing of product trial are interwoven in these clusters of constructs.
\end{abstract}

KEY WORDS: P.T.P., Consumers, Experience, Expertise and Satisfaction

\section{INTRODUCTION}

A consumer can make an informed judgment about the usefulness of a product or satisfaction derived from the consumption of a product based on past experience with the product, which could be favourable or unfavourable, which ever is the case a decision has been taken at that level of abstraction. But the important thing to note is that, this decision or judgment is premised on the individual's subjectivism and perception of what usefulness or satisfaction means. The way customers measure or evaluate a product's value or usefulness is quite different from what manufacturers or sellers do. For experience consumers that are familiar with a particular company's brand, usefulness and satisfaction could mean repeat purchases of the same product in future, and more market can be created for the company, depending on what information buyers give to untapped market. This is because they have benefited much from the consumption of the product. But on the part of the producer or seller, if a product meets the needs and desires of the target market in terms of satisfaction, the product will be in high demand and the producer or seller's evaluating instrument is the rate of turn-over. How the seller can replenish stock to fill the gap of finished stock. On the other hand if turnover rate and mark-up fall short of expectation, it means un-acceptance and dissatisfaction for the seller or company's brand.

It is imperatively difficult for a buyer to perceive favourable impact of a product at the first sight of the product without initial trial that may lead to subsequent decision. Such buyer or customer needs series of information processing regarding the physical configuration, quality and value of the product. In processing information about the company's brand or product, a consumer would need to perceive these attributes just in the same manner of the informant or sales agent in other to create a positive impact; otherwise the reverse is the case. This leads us to the core of the studyconsumers processing of products as first timer in the trail stage. What then is product trail? It is defined as consumer's first usage experience with a company's brand or product that is a critical factor in determining brand beliefs, attributes, and purchase intentions (Marks and

Sunday O. E. Ewah, Faculty of Management Sciences, Cross River University of Technology, Ogoja Campus, Nigeria

Atim E. Esang, Faculty of Management Sciences, Cross River University of Technology, Ogoja Campus, Nigeria 
Kamins, 1988). This provides the consumers with direct sensory or physical conduct with the tangible product. Therefore before the conceptualization and development of a model of consumers trail processing in the mix of obscurity, it is the desire of this study to delve into brief literature of product as a generic word. Furthermore, the remaining part of the study include; product concept, levels of product, consumers' product knowledge, others are product life cycle and product trial, methodology of consumers processing of product trail, summary and conclusion.

\section{Product as a Concept}

It implies a bundle of physical and psychological satisfaction that consumers receive from a purchase (Nwokoye, 1996). From the literature of product development, it is expected that each trial of a product or particular brand by a consumer, such a brand should be capable of meeting consumers will prefer product that give them the best satisfaction In terms of high desires and needs. This is because consumer's quality, performance and possible future purchase decision

Products are used by marketers to satisfy the needs and wants of consumers, but how these customers or buyer process new product trial is most important to them and a thing of concern to marketers and producers. What consumers want in a product is essentially the service benefit or solution to their problems. Thus, the idea of product as potential customer's satisfier is very important in every effort to appeal to first timers. When a company markets a product, what it is really marketing is the expected satisfaction, use or benefit that the customer wants (Mc Carthy and Perreault, 1982).

Marketers and manufacturer should not confuse the physical product with the functional aspect. In other words what really is important in a product is the services or benefits which the product will offer, and ease or facilitate customer's processing of product trial. Therefore, manufacturers should be more preoccupied with those good qualities and features of a product that would enhance consumer's satisfaction. This is because consumers or buyer will base their product trial decision on the above salient factors or even more discerning ones.

\section{Leaves of Product}

There are five levels of customer value hierarchy, which include; core benefit, basic product, augmented product and potential product.

Core Benefit: This means the fundamental service or benefit that the customer is really buying. This of course is the most important level of product.

Basic Product: This is the specific form of the tangible product or item which helps to deliver the core benefit. It is equally referred to as generic product.

Expected Product: Here the marketer or product developer prepares an expected product, with all the set of attributes and conditions that would spur consumer's trial decision.

Augmented Product: These are the extra benefit attach to the product. This enables a company or a marketer to offer benefits that exceed customer's expectations.

Potential Product: This encompasses all the possible augmentation and transformation the product might undergo in the future. Thus it requires companies to be innovative and creative by searching for new ways to satisfy customers through their product offer.

\section{Consumers' Product Knowledge}

Peter and Olson in 1996 listed three types of product knowledge which consumers may be privilege to have. They include;

$\begin{array}{llr}\text { - } & \text { Knowledge of Product } & \text { Feature: } \\ \text { Companies should work } & \text { towards } \\ \text { ascertaining } & \text { which } & \text { product }\end{array}$ characteristics and attribute appeal most to consumers. What they mean to consumers, and how consumers use this knowledge in cognitive processes, such as product trial and the final decision of making the purchase.

Knowledge of Product Benefit: Consumers often think about product and brands in terms of their consequences, not their attributes. Consequences are outcome that occur to a consumer when the product is purchased and put to use. These outcomes could necessitate to acceptance or rejection in the future.

Knowledge of Product as Value Satisfiers: Consumers also have knowledge about the personal symbolic values that products and brands help them to satisfy or achieve (Ozo, 2005). Values are buyers or consumers broad 
life goals and involve the feelings and emotions associated with such goals and needs. Since they represent important consequences that are personally relevant, values are associated with strong affective (emotions, feelings, belief) responses. Satisfying a value usually elicits strong affect (happiness, joy, satisfaction), while blocking a value produces negative affect (rejection, frustration).

\section{Product Life Cycle and Product Trial}

Nickels, et al (1999) defined product life cycle as a theoretical model of what happens to sales and profit for a product class overtime. Thus it is a concept that seeks to describe the product sales, profits, customers, competition and marketing emphasis from inception to removal from the market (Ewah, 2007). It has five or more life stages, depending on the product.

Product Development: This is the first stage in the product life cycle, because it begins with the introduction of new product idea by the company or marketer. During this period, sales are at zero level while the company investment cost increases. This time also characterizes the period consumers have not seen or heard about the product, talk less of product trial and processing.

Introduction Stage: It is the period in which the product is first distributed through marketing outlets and made available for purpose. This period is a characteristic of slow sales growth, non existence of profit and heavy expenses to create awareness and acceptance. This period implies consumer's first contact with the product.
Growth Stage: Now is the time for rapid market acceptance and increasing profit because the product's sale has started increasing. Equally competitors start coming into the market and each tries to develop the best product design. While some competitors copy the most successful product, the increase in competitors leads to more number of distribution outlets, and promotion becomes the weapon of communication for trial especially amongst untapped market.

Maturity Stage: This stage is characterized by increasing sales but declining profit level. The competitive pressure may require companies lowering their price to reach more consumers. Profit level often decline because of increased marketing outlay or promotion cost to promote trial and defend it against competition. This stage normally last longer than any other stage in a product life cycle.

Decline or Demise Stage: At this stage of a product life cycle, firms can cut back on marketing or promotion, terminate a product completely or prune some. This is as a result of decrease in sales which may have been necessitated by intense competition in the market, change in consumer's taste, improved technology in other firms, etc. A consumer's processing of product trial at this stage of its life cycle has detrimental effect. How would the consumer perceive a product that is almost not commanding a reasonable share of the market? Definitely such a product will be viewed with negative nostalgia. 


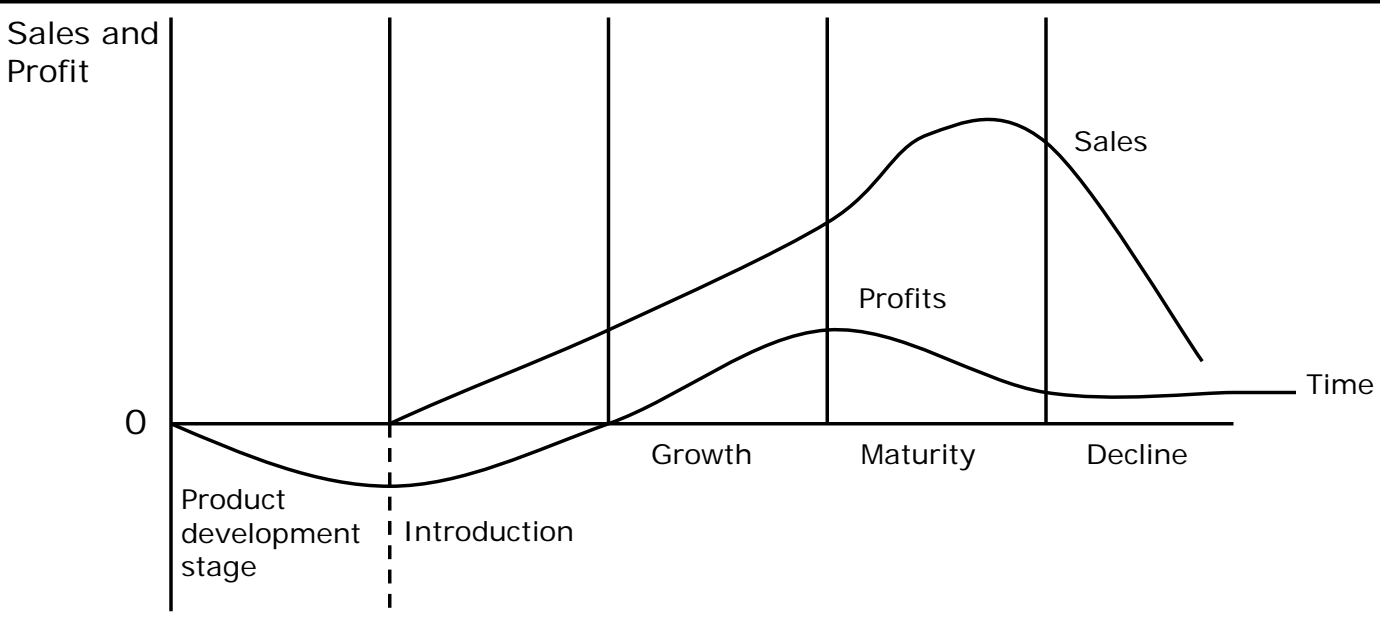

Source: Adopted from Ewah (2007).

Figure 1: Product Life Cycle (PLC)

Table 1: Summary of product Life Cycle Characteristic, Objectives and Strategies.

\begin{tabular}{|c|c|c|c|c|c|}
\hline Characteristics & \multicolumn{2}{|l|}{ Introduction } & Growth & Maturity & Decline \\
\hline Sales & \multicolumn{2}{|l|}{ Low sales } & $\begin{array}{l}\text { Rapidly rising } \\
\text { sales }\end{array}$ & Peak sales & Declining sales \\
\hline Cost & \multicolumn{2}{|c|}{ High cost per customer } & $\begin{array}{l}\text { Average cost per } \\
\text { customer }\end{array}$ & $\begin{array}{l}\text { Low cost per } \\
\text { customer }\end{array}$ & $\begin{array}{l}\text { Low cost per } \\
\text { customer }\end{array}$ \\
\hline Profits & \multicolumn{2}{|l|}{ Negative } & Rising Profit & High profits & Declining profits \\
\hline Customers & \multicolumn{2}{|l|}{ Innovators } & Early adopters & Middle majority & Laggards \\
\hline \multicolumn{6}{|l|}{$\begin{array}{l}\text { Marketing } \\
\text { Objectives }\end{array}$} \\
\hline & \multicolumn{2}{|c|}{$\begin{array}{l}\text { Create product awareness } \\
\text { and trial }\end{array}$} & $\begin{array}{l}\text { Maximize market } \\
\text { share }\end{array}$ & $\begin{array}{l}\text { Maximize profit } \\
\text { while defending } \\
\text { market share }\end{array}$ & $\begin{array}{l}\text { Reduce } \\
\text { expenditure and } \\
\text { milk the brand }\end{array}$ \\
\hline \multicolumn{6}{|l|}{ Strategies } \\
\hline Product & $\begin{array}{l}\text { Offer a basic } \\
\text { product }\end{array}$ & \multicolumn{2}{|c|}{$\begin{array}{l}\text { Offer product } \\
\text { extensions, service, } \\
\text { warranty }\end{array}$} & $\begin{array}{l}\text { Diversify brand and } \\
\text { models }\end{array}$ & $\begin{array}{l}\text { Phase out weak } \\
\text { items }\end{array}$ \\
\hline Price & Use cost - plus & \multicolumn{2}{|c|}{ Price to penetrate } & $\begin{array}{l}\text { Price to match or } \\
\text { beat competitors }\end{array}$ & Cut price \\
\hline Distribution & $\begin{array}{l}\text { Build selective } \\
\text { distribution }\end{array}$ & \multicolumn{2}{|c|}{$\begin{array}{l}\text { Build intensive } \\
\text { distribution }\end{array}$} & $\begin{array}{l}\text { Build more intensive } \\
\text { distribution }\end{array}$ & $\begin{array}{l}\text { Go selective: } \\
\text { phase out } \\
\text { unprofitable outlets }\end{array}$ \\
\hline Advertising & $\begin{array}{l}\text { Build product } \\
\text { awareness among } \\
\text { early adopters and } \\
\text { dealers }\end{array}$ & \multicolumn{2}{|c|}{$\begin{array}{l}\text { Build awareness and } \\
\text { interest in the mass } \\
\text { market }\end{array}$} & $\begin{array}{l}\text { Stress brand } \\
\text { differences and } \\
\text { benefits }\end{array}$ & $\begin{array}{l}\text { Reduce to level } \\
\text { needed to retain } \\
\text { hard - core loyals }\end{array}$ \\
\hline
\end{tabular}




\begin{tabular}{|l|l|l|l|l|}
\hline Sales Promotion & $\begin{array}{l}\text { Use heavy sales } \\
\text { promotion to } \\
\text { entice trial }\end{array}$ & $\begin{array}{l}\text { Reduce to take } \\
\text { advantage of heavy } \\
\text { consumer demand }\end{array}$ & $\begin{array}{l}\text { Increase to } \\
\text { encourage brand } \\
\text { switching }\end{array}$ & $\begin{array}{l}\text { Reduce to minimal } \\
\text { level }\end{array}$ \\
\hline
\end{tabular}

Source: Culled from Kotler and Armstrong (2001)

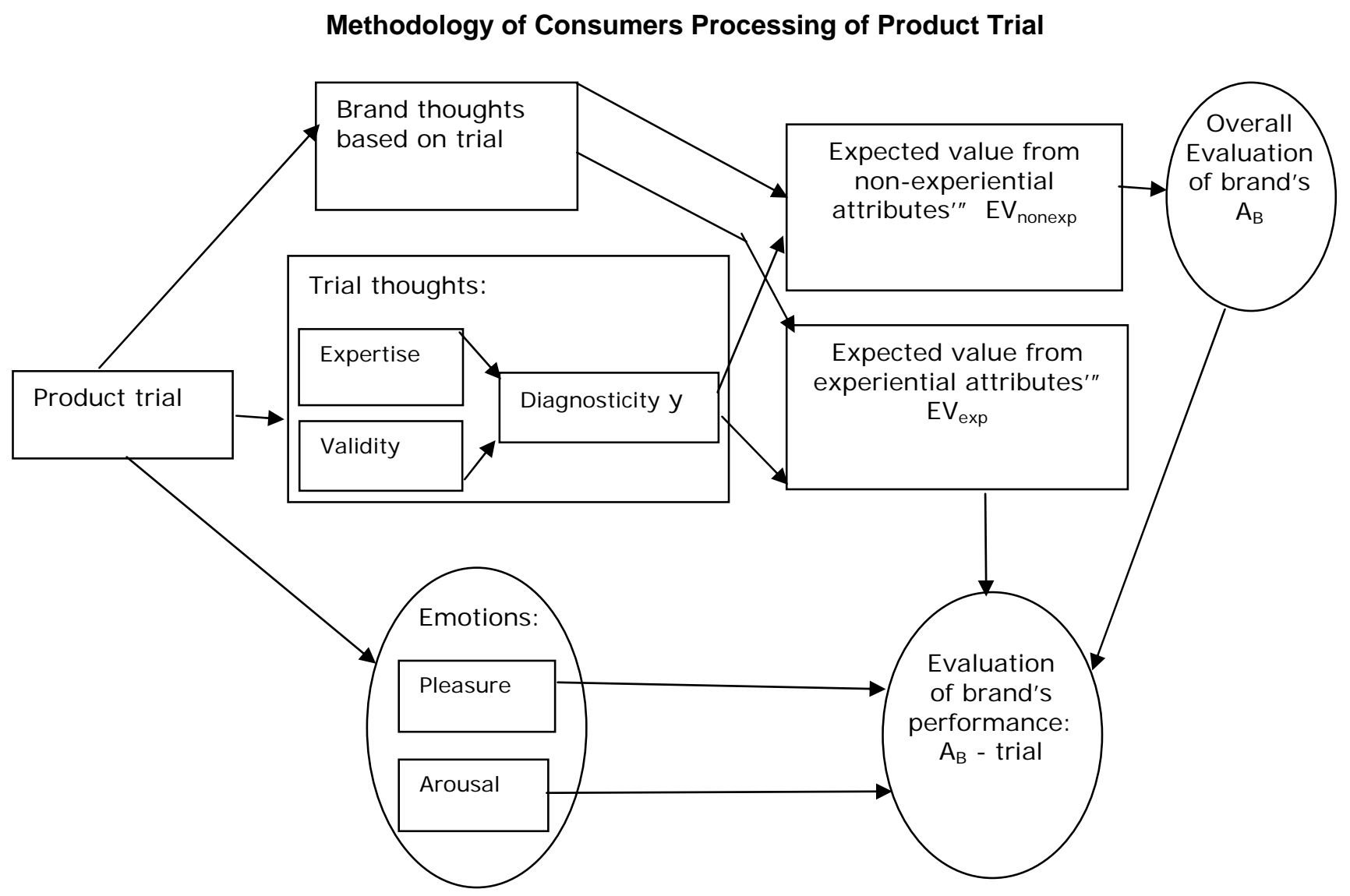

Figure 1: Model of Consumers Processing of Product trial

Source: Culled from Kempf and Smith (1998: 326). 
Based on the scholarly work of Kempf and Smith in 1998, product trial processing starts with some combination of visual, tactile, auditory and/or taste data that are channeled to the sensory register for attention and evaluation. The memory of these stimuli needs to be relatively high because consumers are normally in an evaluative mind-set during the product trial and are motivated to remember the brand's performance. Also sensory information is self-generated hence there is maximum trust worthiness. Craik and Lockhart (1972); Greenwald and Leavitt (1984); and Maclnnis and Jaworski (1989), confirmed that, the degree of personal evaluation used in encoding can affect subsequent recall strongly and that direct experience should create both personal and elabourate memory codes because of its vividness (Fazio and Zanna, 1978). Consumers are subject to have relatively high involvement with a trial when it serves an information function. That is, the trial is used to determine which attributes are associated with the firm's brand. According to smith and Swinyard (1982), when a trial serves an information function, consumers can be expected to make a conscious effort to evaluate the brand's salient experiential attributes. This is because the main purpose of trial is to find out if consumers like the particular brand.

\section{CONCEPT USED IN THE MODEL}

Experiential Attributes: These are those features or characteristics of a product that can be evaluated directly by trial. Such attributes can be in the form of content, weight, hardness or taste of the product. It is important to note that when consumers consciously evaluate the brand's experiential attributes during trial, they are likely to produce a series of brand-related thoughts. This could be positively perceived or negatively perceived.

Non-experiential Attributes: These are indirectly observable features that are attached to the product to aid information processing during trial by the consumer. These equally implies credence attributes that are conveyed better through indirect marketing tools poor information, such as advertising (Darby and Karni, 1973) and (Wright and Lynch 1995). Non-experiential attributes, such as, the aesthetic value of a product of vitamin content of a tin of bourvita can be ascertain or judged based on a single trial experience which the consumer finds himself.
Although in some instances beliefs and perception about non-experiential attributes are influenced more effectively by external forces (like advertising or other promotional tools) apart from the individual personal decision during the trial period. However consumers sometimes make inferences about non-experiential attributes, even when they can not-substantiate or validate their trial experience with the product. But such inferential brand beliefs are normally weaker and less confidently held, than experiential beliefs formed through direct experience.

Perceived Validity of Product Trial: This refers to the extent a particular product trial is perceived to perform in the mind of consumers. It is a representative of a product's true performance in terms of its credibility and enhancement. When cues that threaten product trial validity occur, there is every likely hold that consumers may think about validity overtly. For example when a customer has insufficient time to test the product adequately or if the trial is suspected to be unrealistically manipulated and vague, such are the multiple examples of invalid trial that can result to customers discontinuing the trial.

Consumer Perceived Expertise: This trialrelated cognition is the magnitude to which consumers feel confident in their ability to process the information provided through the trail. Thus it is the subjective judgment of a product performance during trial and not consumer's objective knowledge level. Perceived expertise is a function of the consumer's degree of prior experience and when it is at comfortable level, trial cognitions regarding expertise are likely to be produced consciously. It is rather beliefs about expertise that are likely to become conscious if they are activated by a cogent cue. This means that trial cognitions is being governed by a management-by-exception rule, that is, most explicit trial cognitions regarding perceived expertise will occur when factors detrimental to expertise are present or conditions are extremely favourable.

Perceived Diagnosticity of Product Trial: In the model it represents the extent to which the consumer believes that the product trial is useful in evaluating the firm's brand or products attributes. In addition to being influenced by perceived expertise and perceived validity, trial diagnosticity is affected by-whether the attribute being evaluated is experiential or nonexperiential. Therefore, a product trial will be 
perceived as most diagnostic when the product salient attributes are mostly experiential (i. e. attributes that can be directly evaluated during trial) and when there are no doubts about expertise or trial validity. Conversely product trial would be perceived as relatively non diagnostic when doubts about validity or expertise exist and when the brand or product's salient attributes or characteristic are mostly non-experiential, because by definition, product trial does not convey direct information on these features. The marketing implication is that, the resulting brand beliefs and acceptance for the product by consumers will be weak or held with less confidence (Koriat Lichtenstein, and Fischoff 1980). When consumer's experience a diagnostic product trial, the product or brand beliefs and acceptance is stronger and held with more confidence, thus there is a positive relationship between trial diagnostic and evaluation value (EV).

Emotions: Emotional components in the model are pleasure and arousal. It is an established fact that consumers emotional temperament or balance, influence the way they process product trial. This is because trial involves direct physical contact with the product and a consumer's affective response includes emotional reactions to the product or the experience from the trial (Mano and Oliver 1993).it is quite logical to say that emotions elicited during product trial is important because it comes from the individual's perspective and it is not being influence by external factor. Smith (1993) attributed the greater effects of trial on brand attitudes to cognitive antecedents, such as belief confidence and to a lesser degree, belief strength.

Evaluations of Trial Performance (AB-Trial): This is the evaluation of the brand or product performance for acceptance or rejection during the first usage experience. AB-Trial construct represents the trial performance's contribution to overall brand attitude (AB). It has both cognitive and affective antecedents. At the cognitive level, evaluative value (EV) from experiential attributes has a direct impact on AB-Trial when ever consumer consciously analyzes the brand's performance. The goal of any product trial is that EV experiential should play a major role in determining $A B$-trial, though the magnitude of the effect may depend on the number of experiential attributes involvement in the trial and trial processing intentions. Emotional components, such as pleasure and arousal experienced during product trial will contribute to $A B$-trial and depending on product type, may be a major determinant of $A B-$ Trial.

The marketing relevance of the trial model is the development of the AB-Trial construct which has a diagnostic value needed by marketers to analyze consumer' overall evaluation of brands performance during trial.

Brand Attitude or Attitude towards the Brand (AB): This is the consumer's overall or aggregate evolution of the product trial. Consumer's attitude towards a brand may be favourable or unfavourable. The former implies acceptance and possible decision to buy a particular company's brand or product. While the later signifies rejection and negative attitude towards the actual purchase decisions. Brand attitude will be more favourable for products that are easily process during trial, especially when they meet the requirement of consumers.

\section{SUMMARY AND CONCLUSION}

The model indicates that perceived expertise influence perceived diagnosticity of the trial for both experiential and non-experiential attributes for some class of products especially for non complex ones. Therefore, for a trial to be diagnostic, the consumer must fell sufficiently expert in processing the information offered in the trial. Thus perceived diagnosticity has a strong effect on product trial based beliefs and suggests that marketers and producers should take into consideration how diagnosticity will influence product trial and response for specific product and attributes classification.

Furthermore, the more expert consumer believed themselves to be more diagnostic, the product trail is perceived to be correct. Therefore, marketers and producers can gain differential advantage in their trial programmes if they can make consumers feel competent to judge the trial. This height can be achieved through enlightenment campaigns for complex products, package information, pretrial promotion, etc; for consumers to create awareness and preference. Moreover, the higher the perceived expertise the more likely consumers will interpret the product to be successful, since there are familiar with the product, that the benefit can be deduce based on first hand experience. When consumers' expertise is low it will be difficult for consumers to be certain or sure of the satisfaction a product will give during trial processing, especially when 
complex product are involved. Though, with the aid of other promotional tools that is targeted towards consumers, to induce consumer product trial decision by the marketers, they might be lured into buying.

\section{REFERENCES}

Alba, J. W. and Hutchinson, J. W., 1987. Dimensions of Consumers Expertise. Journal of Consumer Research, 13: (March), 411- 454.

Craik, F. I. and Lockhart, R.S., 1972. Levels of Processing: A Framework for Memory Research, Journal of Learning and Verbal Behaviour. 11: pp 167-684.

Darby, M. R. and Karni, E., 1973. Free Competition and the Optional Amount of Fraud, Journal of Law and Economics. 16: (April), 67- 88.

Ewah, S., 2007. Foundation of Marketing Principles and Practice. Pafelly Printers and Publishers; Ogoja. Nigeria. Reprint Edition.

Fazio, R.H. and Zanna, M.P., 1978. On the Predictive Validity of Attitudes: The Role of Direct Experience and Confidence. Journal of Personality, 46: (June), 228 43.

Greenwald, A. G. and Leavitt, C., 1984. Audience Involvement in Advertising: Four levels. Journal of Consumer Research,. 11: (June), 581-592.

Kempf, D. S. and Smith, R. E., 1998. Consumer Processing of Product Trial and the Influence of prior Advertising: A Structural Modeling Approach. Journal of Marketing Research, 35: (August), Pp.325 - 338 .
Kotler, P. and Armstrong, G., 2001. Principles of Marketing. Prentice-Hall of India, New Delhi, $9^{\text {th }}$ Edition.

Koriat, A., Lichtenstein, S. and Fischoff, B., 1980. Reasons for Confidence. Journal of Experimental Psychology: Human Learning and Memory, 6: (March), 107118.

Maclnnis D. J. and Jaworski, B. J., 1989. Information Processing from Advertisement: Toward an Integrative Frame work. Journal of Marketing 53: (October), 1- 23.

McCarthy, E. J. and Perreault, W.D., 1982. Basic Marketing Boston; Richard D. Irwin Inc.

Mano, H. and Oliver, R. L., 1993. Assessing the Dimensionality and Structure of the Consumer Experience: Evaluation, Feeling, and Satisfaction, Journal of Consumer Research. 45: (May), 101 120.

Ozo, J. U., 2005. Product Development and Management, Enizol Ventures Publishers, Enugu. Nigeria.

Peter, J. P. and Olson, J., 1996. Consumer Behaviour and Marketing Strategy, Chicago. Irwin. $4^{\mathrm{TH}}$ Edition. 